\title{
Lactation Performance by Dairy Cows Fed Wet Brewers Grains or Whole Cottonseed to Replace Forage ${ }^{1,2}$
}

\author{
J. L. Firkins, D. I. Harvatine ${ }^{3}$, J. T. Sylvester, and M. L. Eastridge \\ Department of Animal Sciences, \\ The Ohio State University, \\ Columbus, 43210
}

\section{ABSTRACT}

Holstein cows starting at wk 8 of lactation were used to evaluate lactation performance when wet brewers grains, whole linted cottonseed, or starch-coated whole linted cottonseed (Easiflo ${ }^{\mathrm{TM}}$ ) were substituted for forage. The wet brewers grains were added to diets to decrease forage neutral detergent fiber from $21 \%$ incrementally down to $15 \%$ while simultaneously decreasing nonfiber carbohydrate concentration from $40.3 \%$ down to about $33.8 \%$. The cottonseed treatments all had similar concentrations of forage neutral detergent fiber (15\%) and nonfiber carbohydrates (33.1 and 36.0\%). Dry matter intake and milk production were similar across treatments. Milk fat percentage was decreased for Easiflo versus whole linted cottonseeds, but no other responses were detected. The current National Research Council (NRC) energy model was evaluated using individual cow data that were averaged over the entire 16wk treatment period. For treatment means, the output of energy averaged $99 \%$ of the net energy of lactation intake, indicating very good corroboration of the model to account for energy usage for a group of cows. However, the ability to predict energy usage for individual cows was less accurate based on the comparison of residuals of observed and predicted body weight change regressed against predicted body weight change, apparently because of compounding of random errors in this prediction, which was alleviated over a larger number of observations. These results also corroborate current NRC guidelines for minimum forage neutral detergent fiber concentrations for lactating cows past the calving transition period.

Received October 16, 2001.

Accepted April 2, 2002.

Corresponding author: J. L. Firkins; e-mail: firkins.1@osu.edu.

${ }^{1}$ Salaries and research support were provided by state and federal funds appropriated to the Ohio Agricultural Research and Development Center, The Ohio State University. Manuscript number 35$01 \mathrm{AS}$.

${ }^{2}$ Additional research support was provided by Cotton Incorporated, Raleigh, NC, and Commodity Specialists, Columbus, OH.

${ }^{3}$ Current Address: Agway Feed and Nutrition, 512 West King St., Shippenburg, PA 17257.
(Key words: forage neutral detergent fiber, nonfiber carbohydrate, wet brewers grain, whole linted cottonseed, dairy cow)

Abbreviation key: ECM = energy-corrected milk, NFC = nonfiber carbohydrates, $\mathbf{W B G}=$ wet brewers grains, $\mathbf{W C S}=$ whole linted cottonseed.

\section{INTRODUCTION}

The need for effective fiber to stimulate chewing, especially rumination to stimulate salivary buffering, has been addressed (Mertens, 1997; Varga et al., 1998). Coupling production with neutralization of fermentative acids, the NRC (2001) provides minimum forage NDF guidelines from 19 to $15 \%$ so long as the maximum nonfiber carbohydrate (NFC) concentration is also decreased from 44 to $36 \%$. A recent study (Slater et al., 2000) indicated that forage NDF could be decreased even further when whole linted cottonseeds (WCS) were used as a forage substitute. Whole linted cottonseeds have stimulated rumination better than other nonforage fiber sources (Clark and Armentano, 1993). Varga et al. (1998) noted that the variation in effectiveness of nonforage NDF is greater than that for forage NDF because of variation in particle size and retention time in the rumen. Some of the variation could result from increased particle length or dietary percentage of forage, which helps entrap and slow ruminal passage of fibrous byproducts (Grant, 1997). Effectiveness values (chewing response relative to forage) of NDF from WCS ranged from $50 \%$ of NDF from long-cut alfalfa silage to $127 \%$ from short-cut alfalfa silage (Mooney and Allen, 1997). Because WCS might become entrapped in the ruminal mat to retard passage (Coppock et al., 1985), we hypothesized that the physical characteristics of WCS make them nearly as effective as forage NDF when forage NDF is adjusted to $15 \%$ of DM.

Easiflo cottonseeds are a commercial source of WCS with linters matted down with starch for better flow and mixing capabilities. Earlier research (Bernard et al., 1999) showed that 5.0\% cornstarch increased ease of handling, but 2.5\% (Bernard, 1999) cornstarch optimized feeding characteristics. These studies were done 
with forage NDF above $21 \%$ of DM. The value of WCS is apparently enhanced in diets with low forage NDF, but the efficacy of Easiflo has not been verified in this situation. The first objective was to compare lactation performance in a continuous lactation trial by cows fed Easiflo cottonseeds to unprocessed WCS in low-forage diets with decreased NFC concentration.

Brewers grains NDF has been estimated, based on chewing response, to have effectiveness values ranging from 32 to $80 \%$ of alfalfa silage NDF, despite the low predicted effectiveness (24\%) based on particle size (Mertens, 1997). Younker et al. (1998) noted that, when dried brewers grains replaced forage, DMI numerically increased by $4.9 \%$ (not significant), but when they replaced concentrate, DMI decreased significantly (by 9.3\%) because of the combined filling effects of forage and dried brewers grains. We hypothesized that the filling effect of wet brewers grains (WBG) would be decreased or eliminated when they replaced forage NDF; however, because WBG were hypothesized to be less effective at stimulation of chewing than WCS, DMI and milk fat percentage might decrease for low-forage diets with WBG compared with WCS. Our second objective was to progressively replace forage NDF with NDF from WBG while concomitantly decreasing NFC to determine an optimal replacement rate of WBG for forage $\mathrm{NDF}$ as evaluated by continuous lactation performance.

\section{MATERIALS AND METHODS}

Sixty cows (30 primiparous and 30 multiparous) were used in an 18-wk study. During wk 8 and 9 of lactation, all cows were fed the high-forage control diet (Table 1); from wk 10 to 25 of lactation, cows were blocked and randomly allotted within blocks to the control diet, to three diets with increasing concentrations of WBG, or to two diets with whole cottonseed in the conventional form (termed WCS) or when the linters were matted down with 2.5\% cornstarch (Easiflo; produced by Commonwealth Gin, Buckhorn, VA). Multiparous cows were blocked by calving date and by predicted mature-equivalent milk production. Primiparous cows were blocked by calving date and by average milk production from wk 8 to 9 of lactation. All cows were injected with Posilac (Monsanto, St. Louis, MO), starting on wk 10 of lactation and every $14 \mathrm{~d}$ thereafter.

Wet brewers grains (52.6\% NDF and $12.9 \%$ neutral detergent insoluble CP; DM basis) were added to replace forage NDF and to reduce NFC incrementally (Table 1). The WBG were delivered in 20-t lots as needed (approximately every 2 to $4 \mathrm{wk}$ ), stored in plastic bags, and kept covered until needed. Diets with WCS or Easiflo cottonseeds (both about $52 \% \mathrm{NDF}$ on a DM basis) were formulated to provide the same forage NDF and NFC as the highest WBG diet. Both sources of WCS were delivered at the beginning of the trial and stored in dry locations throughout the study. Soybean hulls and corn were formulated to provide 41.5, 40.0, 38.5, $37.0,37.0$, and $37.0 \% \mathrm{NFC}$ in the DM of high-forage control; low, medium, and high WBG; WCS; and Easiflo cottonseed diets, respectively. Forage NDF was balanced to be $20.8,18.7,16.7,14.7,14.7$, and $14.7 \%$, respectively. Constraints prevented forage NDF and NFC from being greater than 21 and $42 \%$ for the control to be consistent with industry standards, and NFC was minimized at $37.0 \%$ to prevent $\mathrm{NE}_{\mathrm{L}}$ concentration from declining further with increasing addition of WBG. Tallow and roasted soybeans were added to equalize crude fat concentration among diets using tabular values from that software. Net energy of lactation was balanced to be $1.78,1.75,1.72,1.69$, and 1.72 , and 1.72 $\mathrm{Mcal} / \mathrm{kg}$ of DM, respectively, using tabular data from NRC (1989). Diets were all balanced to contain $18.0 \%$ CP and 11.1\% RDP. Roasted soybeans, blood meal, and corn gluten meal were used to try to equalize the estimated lysine and methionine in the RUP using equations described by Eastridge and Winkler (1998). Diets were mixed once daily as TMR and fed to individual cows to provide $10 \%$ orts.

Cows were milked twice daily at 0530 and $1600 \mathrm{~h}$. Milk samples were taken at four consecutive milkings each week. Milk samples were analyzed by DHI Cooperative, Inc. (Powell, $\mathrm{OH}$ ) for milk fat and protein analysis by infrared spectroscopy. Data were weighted by production level to provide a weekly average for milk composition. Daily milk production was averaged per week.

Feed offered and feed refused were monitored daily for each cow and averaged per week. Body condition scores (1 to 5 scale; NRC, 2001 ) were assessed at the start of the standardization period (wk 8), at the start of the treatment period (wk 10), and every 4 wk until the day cows went off treatment. Body weight was recorded weekly. Body weight change was calculated by subtracting a BW from the subsequent week's BW. However, the weekly BW change data were averaged over the 2-wk standardization and also from the entire treatment periods because of the variability in BW.

Samples of TMR (about $400 \mathrm{~g}$ as is) were taken weekly, frozen, and later thawed and composited (about $200 \mathrm{~g} / \mathrm{wk}$ ) by month. After lyophilizing, samples were equilibrated with air, a DM determined, and samples were ground in a Wiley mill (Arthur H. Thomas, Philadelphia, PA) to pass a 2-mm screen. A second DM was determined on the ground samples after heating at $105^{\circ} \mathrm{C}$. Dry matter intake was calculated as the difference of feed offered and orts weekly measurements multiplied by the cumulative DM percentage (before and after lyophilization) of the monthly composite. Kjel- 
Table 1. Ingredient composition of diets containing wet brewers grains or cottonseed to replace forage.

\begin{tabular}{|c|c|c|c|c|c|c|}
\hline & \multirow[b]{2}{*}{ Control } & \multicolumn{3}{|c|}{ Wet brewers grains } & \multicolumn{2}{|c|}{ Cottonseed $^{1}$} \\
\hline & & Low & Medium & High & WCS & Easiflo \\
\hline & \multicolumn{6}{|c|}{$\%$ of diet DM } \\
\hline Alfalfa silage & 16.28 & 14.70 & 13.12 & 11.54 & 11.54 & 11.54 \\
\hline Corn silage & 32.56 & 29.40 & 26.24 & 23.08 & 23.08 & 23.08 \\
\hline Corn, ground & 24.20 & 23.78 & 23.40 & 22.98 & 25.30 & 25.30 \\
\hline Wet brewers grains & $\ldots$ & 8.65 & 17.29 & 25.94 & & \\
\hline Whole cottonseed & $\ldots$ & $\ldots$ & $\ldots$ & $\ldots$ & 15.00 & 15.00 \\
\hline Soybean meal, $48 \%$ CP & 9.12 & 6.25 & 3.37 & 0.50 & 6.66 & 6.66 \\
\hline Blood meal & 0.36 & 0.24 & 0.12 & $\ldots$ & 1.34 & 1.34 \\
\hline Corn gluten meal & 2.76 & 1.84 & 0.92 & & 1.90 & 1.90 \\
\hline Roasted soybeans & 4.36 & 3.67 & 2.97 & 2.28 & & \\
\hline Soybean hulls & 5.82 & 7.40 & 8.98 & 10.56 & 12.74 & 12.74 \\
\hline Tallow & 2.06 & 1.54 & 1.02 & 0.50 & & \\
\hline Dicalcium phosphate & 0.64 & 0.64 & 0.64 & 0.64 & 0.64 & 0.64 \\
\hline Limestone & 1.10 & 1.10 & 1.10 & 1.10 & 1.10 & 1.10 \\
\hline Magnesium oxide & 0.18 & 0.18 & 0.18 & 0.18 & 0.14 & 0.14 \\
\hline Potassium chloride & 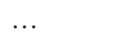 & 0.05 & 0.09 & 0.14 & $\ldots$ & \\
\hline Trace mineralized salt ${ }^{2}$ & 0.50 & 0.50 & 0.50 & 0.50 & 0.50 & 0.50 \\
\hline Vitamin premix ${ }^{3}$ & 0.06 & 0.06 & 0.06 & 0.06 & 0.06 & 0.06 \\
\hline
\end{tabular}

dahl $\mathrm{N}$ and ash were determined for monthly composites as outlined by AOAC (1990). The NDF concentration of samples was measured using a hot ethanol preextraction followed by a urea soak and incubation with heat-stable amylase (Van Soest et al., 1991). This was repeated except without the urea presoaking for the determination of Kjeldahl $\mathrm{N}$ of the NDF residue. The $\mathrm{N} \times 6.25$ was subtracted from NDF because of the high protein contamination of NDF from brewers grains (Younker et al., 1998). Lignin and ADF were analyzed (Goering and Van Soest, 1970), and ADF was corrected for $\mathrm{CP}(\mathrm{N} \times 6.25)$, as described for NDF. Monthly composites were analyzed for fatty acids (Sukhija and Palmquist, 1988). Based on NRC (2001) recommendations, the NFC was calculated by difference after adjusting NDF for CP contamination and adjusting fatty acid concentration for non-fatty acid lipids (adding one percentage unit).

Analyses of monthly composite TMR samples were used to predict the $\mathrm{NE}_{\mathrm{L}}$ concentration of diets as described by Weiss (1993), which converts predicted TDN maintenance to $\mathrm{NE}_{\mathrm{L}}$ at three times maintenance. The $\mathrm{NE}_{\mathrm{L}}$ concentration of monthly composited samples was multiplied times the weekly DMI to determine weekly $\mathrm{NE}_{\mathrm{L}}$ intake. Energy-corrected milk (ECM; 3.5\% fat) was calculated as described by Tyrrell and Reid (1965).

Weekly data for production measurements were analyzed as a randomized complete block design using the MIXED procedure of SAS (1999). Repeated measures within cow were analyzed using the first order autoregressive $[\mathrm{AR}(1)]$ covariance structure, with cow (treat- ment $\times$ block) as the only random effect. For intake of $\mathrm{NE}_{\mathrm{L}}$ (estimated at $3 \times$ maintenance), the MIXED procedure would not converge, so cow was analyzed as a fixed effect using the GLM procedure of SAS. The respective variable from the standardization period (averaged over wk 8 and 9 of lactation) was used as a covariate, and covariate-adjusted least squares means are reported. Because treatment $\times$ time interactions were not significant $(P>0.10)$ with the AR(1) or any other covariance structure tested, means over the entire treatment period (wk 10 to 25 of lactation) were assessed for treatment differences using the CONTRAST statement of SAS. Treatment contrasts included: 1) the linear and 2) quadratic effects of WBG addition in the control and low, medium, and high WBG diets; 3 ) the control compared with the average of WCS diets; 4) the highest WBG diet compared with the average of WCS diets; and 5) WCS versus Easiflo cottonseeds.

Procedures from the current NRC (2001) were also used to assess energy usage by cows. Because no treatment $\times$ time interactions were detected $(P>0.10)$ for production measurements, data needed for the model were averaged over the treatment period. The weighted average (cow-weeks per month) of TMR analyses and the average DMI were entered into the NRC (2001) software to calculate $\mathrm{NE}_{\mathrm{L}}$ concentration and $\mathrm{NE}_{\mathrm{L}}$ intake per cow averaged over the 16 -wk feeding period. To evaluate energy usage, DMI, milk composition (actual protein and fat, but assumed $4.85 \%$ lactose), BCS, and BW were entered into NRC (2001) software to calculate $\mathrm{NE}_{\mathrm{L}}$ used for maintenance, calculate milk energy, and 
Table 2. Chemical composition (DM basis) of wet brewers grains or diets containing wet brewers grains or cottonseed to replace forage.

\begin{tabular}{|c|c|c|c|c|c|c|c|c|}
\hline & \multirow{2}{*}{\multicolumn{2}{|c|}{ Wet brewers grains }} & \multicolumn{6}{|c|}{ Diets } \\
\hline & & & \multirow[b]{2}{*}{ Control } & \multicolumn{3}{|c|}{ Wet brewers grains } & \multicolumn{2}{|c|}{ Cottonseeds $^{1}$} \\
\hline & Mean & $\mathrm{SD}$ & & Low & Medium & High & WCS & Easiflo \\
\hline OM, \% & 96.7 & 0.2 & 94.0 & 94.2 & 93.9 & 94.1 & 94.3 & 94.4 \\
\hline $\mathrm{CP}, \%$ & 33.1 & 1.3 & 17.4 & 17.1 & 17.3 & 17.3 & 17.8 & 17.5 \\
\hline $\mathrm{NDF}, \%$ & 52.6 & 2.9 & 32.0 & 34.4 & 38.7 & 40.9 & 40.0 & 36.9 \\
\hline $\mathrm{NDICP}^{2}, \%$ & 12.9 & 1.5 & 2.30 & 2.42 & 3.17 & 3.83 & 2.65 & 1.89 \\
\hline $\mathrm{ADICP}^{3}, \%$ & 2.64 & 0.49 & 1.00 & 1.02 & 1.43 & 1.43 & 0.98 & 1.06 \\
\hline Lignin, \% & 4.26 & 0.84 & 2.87 & 2.44 & 3.13 & 3.54 & 4.68 & 3.99 \\
\hline Fatty acids, \% & 7.16 & 0.23 & 5.60 & 5.38 & 5.02 & 4.86 & 5.06 & 4.82 \\
\hline $\mathrm{NFC}^{4}, \%$ & & & 40.3 & 38.8 & 35.1 & 33.8 & 33.1 & 36.0 \\
\hline $\mathrm{NE}_{\mathrm{L}}^{5}, \mathrm{Mcal} / \mathrm{kg}$ & & & $\begin{array}{r}4.0 \\
1.82\end{array}$ & $\begin{array}{c}30.0 \\
1.79\end{array}$ & $\begin{array}{l}5.1 \\
1.73\end{array}$ & $\begin{array}{r}5.0 \\
1.70\end{array}$ & $\begin{array}{r}30.1 \\
1.69\end{array}$ & 1.71 \\
\hline $\mathrm{NE}_{\mathrm{L}}^{6}, \mathrm{Mcal} / \mathrm{kg}$ & & & 1.69 & 1.68 & 1.64 & 1.63 & 1.63 & 1.64 \\
\hline
\end{tabular}

predict $\mathrm{BW}$ change. The actual $\mathrm{BW}$ change data and average $\mathrm{BCS}$ were used to calculate $\mathrm{NE}_{\mathrm{L}}$ output for each cow based on its predicted body composition. Energy balance $\left(\mathrm{NE}_{\mathrm{L}}\right.$ intake - $\mathrm{NE}_{\mathrm{L}}$ for maintenance - milk energy) was calculated, and output of $\mathrm{NE}_{\mathrm{L}}$ (maintenance, milk, and BW change) was divided into $\mathrm{NE}_{\mathrm{L}}$ intake. For energy balance and output/input analyses, no covariate adjustment was used, and data were analyzed as a randomized complete block using the GLM procedure of SAS, which assumes the experimental unit (cow) to be a random effect. Contrasts were done as described previously. The residuals of observed minus predicted BW changes were plotted against predicted BW change, and linear regression was used to assess bias.

\section{RESULTS AND DISCUSSION}

No visible molding or heating of WBG were noted. The study was conducted from October to May. Care was taken to ensure that WBG had consistent nutritive quality prior to shipping (Table 2). The CP and NDF (CP-free) concentrations ranged from 31.3 to 35.4 and from 36.4 to $41.6 \%$ of DM, respectively. Similarly, the WCS visibly appeared to hold their quality during the course of the study.

All diets had similar or slightly less CP than formulation values (Table 2), perhaps because of volatilization of ammonia from silages during drying. Although formulated to have similar total lipid concentrations, fatty acid concentration decreased as WBG replaced forage. The WBG in our study had a higher fat concentration (7.2\% fatty acids) compared with that in the NRC (1989; $5.2 \%$ ether extract), which was used to formulate diets.
Harvatine et al. (2001) discussed similar effects on lipid composition as WCS replaced forage. Alfalfa and corn silages averaged 39.6 and $45.0 \% \mathrm{NDF}$, respectively, so actual forage NDF was calculated to be 21.1, 19.1, 17.0, $15.0,15.0$, and $15.0 \%$ during the trial, which is near formulated values. However, NFC was two to three percentage units lower than formulation values. Although the predicted $\mathrm{NE}_{\mathrm{L}}$ concentration at $3 \times$ maintenance decreased by $6.6 \%$ with increasing WBG, the $\mathrm{NE}_{\mathrm{L}}$ concentration was decreased by only $3.6 \%$ when the new NRC (2001) model was used (Table 2).

Dry matter intake was not affected $(P>0.10)$ by decreasing forage NDF and total NFC with increasing WBG in the diet (Table 3). In contrast, when WBG replaced concentrate, DMI decreased linearly (Davis et al., 1983). Younker et al. (1998) reported that DMI decreased when dried brewers grains replaced concentrate but not when it replaced forage. The potential filling effects of WBG and lack of DMI depression in the present study might be explained by digestion kinetics. Although we are unaware of studies measuring the digestion kinetics of WBG, dried brewers grains appeared to have a faster passage rate than forage (corn silage plus alfalfa silage) but a slower NDF digestion rate than that of alfalfa silage (Younker et al., 1998). Replacement of forage with wet corn gluten feed (Allen and Grant, 2000) or a new wet milling corn product (Broddugari et al., 2001) had no consistent effect on overall ruminal NDF digestion rate, whereas passage rate increased in both studies. The replacement of forage NDF with NDF from WBG could have decreased the digestion rate but increased the passage rate of $\mathrm{NDF}$, apparently counteracting effects on rumen fill 
Table 3. Lactation performance by dairy cows fed diets containing wet brewers grains or cottonseed to replace forage. ${ }^{1}$

\begin{tabular}{|c|c|c|c|c|c|c|c|}
\hline & \multirow[b]{2}{*}{ Control } & \multicolumn{3}{|c|}{ Wet brewers grains } & \multicolumn{2}{|c|}{ Cottonseed } & \multirow[b]{2}{*}{ SE } \\
\hline & & Low & Medium & High & WCS & Easiflo & \\
\hline DMI, kg/d & 23.0 & 22.9 & 22.6 & 23.1 & 23.2 & 22.8 & 0.8 \\
\hline Milk, kg/d & 39.4 & 39.4 & 39.5 & 40.2 & 39.0 & 40.3 & 0.9 \\
\hline Fat, $\%^{\mathrm{a}}$ & 3.45 & 3.49 & 3.50 & 3.43 & 3.53 & 3.20 & 0.08 \\
\hline Fat, kg/d & 1.37 & 1.34 & 1.36 & 1.36 & 1.36 & 1.34 & 0.05 \\
\hline Protein, \% & 3.12 & 3.13 & 3.14 & 3.10 & 3.16 & 3.15 & 0.03 \\
\hline Protein, kg/d & 1.23 & 1.23 & 1.22 & 1.24 & 1.24 & 1.27 & 0.03 \\
\hline $3.5 \% \mathrm{ECM}^{3}, \mathrm{~kg} / \mathrm{d}$ & 39.2 & 38.7 & 38.9 & 39.4 & 38.7 & 39.5 & 1.0 \\
\hline Body condition score & 2.49 & 2.55 & 2.52 & 2.33 & 2.45 & 2.50 & 0.09 \\
\hline $\mathrm{BW}, \mathrm{kg}$ & 630 & 611 & 623 & 615 & 619 & 621 & 5 \\
\hline \multicolumn{5}{|l|}{$\mathrm{NE}_{\mathrm{L}}^{4}, \mathrm{Mcal} / \mathrm{d}$} & 0.42 & 0.43 & 0.09 \\
\hline Intake & 38.6 & 37.7 & 37.1 & 37.1 & 38.8 & 37.2 & 1.4 \\
\hline \multicolumn{8}{|l|}{ Output } \\
\hline Maintenance & 10.1 & 10.0 & 9.7 & 9.9 & 10.0 & 9.9 & 0.2 \\
\hline BW gain & 2.0 & 1.4 & 2.4 & 2.2 & 2.3 & 2.2 & 0.4 \\
\hline Milk & 27.6 & 26.4 & 27.0 & 26.7 & 27.5 & 26.7 & 1.0 \\
\hline Output/Intake & 0.986 & 0.975 & 0.996 & 0.992 & 0.974 & 0.989 & 0.026 \\
\hline Milk energy $/ \mathrm{NE}_{\mathrm{L}}$ intake ${ }^{4}$ & 0.723 & 0.707 & 0.733 & 0.723 & 0.713 & 0.721 & 0.023 \\
\hline $\mathrm{NE}_{\mathrm{L}}$ balance ${ }^{4}, \mathrm{Mcal} / \mathrm{d}$ & 0.9 & 1.3 & 0.3 & .5 & 1.3 & 0.6 & 1.1 \\
\hline
\end{tabular}

${ }^{a}$ Whole cottonseeds vs. Easiflo cottonseeds $(P<0.01)$. No other contrasts were significant $(P>0.10)$.

${ }^{1}$ All data are covariate-adjusted least squares means except $\mathrm{NE}_{\mathrm{L}}$ data calculated by NRC (2001).

${ }^{2} \mathrm{WCS}=$ Whole linted cottonseed; Easiflo $=$ WCS coated with $2.5 \%$ cornstarch to mat the linters.

${ }^{3} \mathrm{ECM}=$ Energy-corrected milk.

${ }^{4}$ Calculated using NRC (2001) equations. The BW loss was estimated from Table 2-4, the $\mathrm{NE}_{\mathrm{L}}$ of milk was taken from Equation 2-16, and the $\mathrm{NE}_{\mathrm{L}}$ concentrations of diets were predicted from the computer model. $\mathrm{NE}_{\mathrm{L}}$ balance $=\mathrm{NE}_{\mathrm{L}}$ intake $-\mathrm{NE}_{\mathrm{L}}$ from milk $-\mathrm{NE}_{\mathrm{L}}$ used for maintenance. Data were averaged over the entire 16 -wk treatment period.

and, therefore, DMI in this study. Firkins (1997) noted that DMI was decreased when forage NDF was decreased below $14 \%$ in several studies when byproducts other than WCS were used to decrease forage NDF, apparently because of insufficient effective fiber in the diet. Allen (2000) noted that DMI by lactating cows was maintained in most studies when nonforage fiber sources replaced forage, but increased ruminal degradability of starch depressed DMI in three studies. Therefore, if NFC (and presumably intake of rumendegradable starch) were decreased with increasing concentration of WBG in the diet, DMI should not be depressed. All WBG diets in the current study had $\geq 15 \%$ forage NDF, supporting the potential for WBG to serve as a partial forage replacement in diets meeting NRC (2001) guidelines for forage NDF and NFC.

The DMI by cows fed either form of cottonseed were similar to those fed the control or the high-WBG diet. The starch coating of Easiflo is rapidly degraded (Bernard et al., 2001). Because DMI was similar for Easiflo cottonseeds and WCS, the matted linters of Easiflo probably reverted back to their unmatted state after the starch coating was degraded, providing similar rumination stimulation compared with the diet with WCS. Sequential substitution of alfalfa NDF with NDF from WCS increased DMI linearly (Harvatine et al., 2002a) but maintained total chewing time (Harvatine et al., 2002). Slater et al. (2000) showed that DMI was increased when forage NDF was decreased below $10 \%$ of DM so long as NFC was decreased. In that study, total chewing time was decreased by $43 \mathrm{~min} / \mathrm{d}$ (not significant) for the WCS diet compared to the control. The DMI increased by $0.8 \mathrm{~kg} / \mathrm{d}$ when WCS replaced longcut alfalfa silage but increased by $2.7 \mathrm{~kg} / \mathrm{d}$ when it replaced short-cut alfalfa silage (significant interaction) in another study (Mooney and Allen, 1997).

Milk yield was not affected by cottonseed treatments. Although milk fat percentage was decreased $(P<0.01)$ for Easiflo compared with WCS, production of fat and $3.5 \%$ ECM were similar $(P>0.10)$ among cottonseed treatments. Chewing measurements evaluating Easiflo cottonseed would be needed to explain if the lower fat percentage was related to decreased effectiveness to stimulate chewing, rapid degradability of the starch coating, or to a dilution response, but the lack of response in milk fat yield or other measurements would support the hypothesis that Easiflo cottonseeds have a similar or only marginally lower effectiveness compared with unprocessed WCS.

Increasing WBG inclusion in the diet did not affect production of milk, milk fat, milk protein, BCS, or BW change (Table 3). To further assess the lack of response 


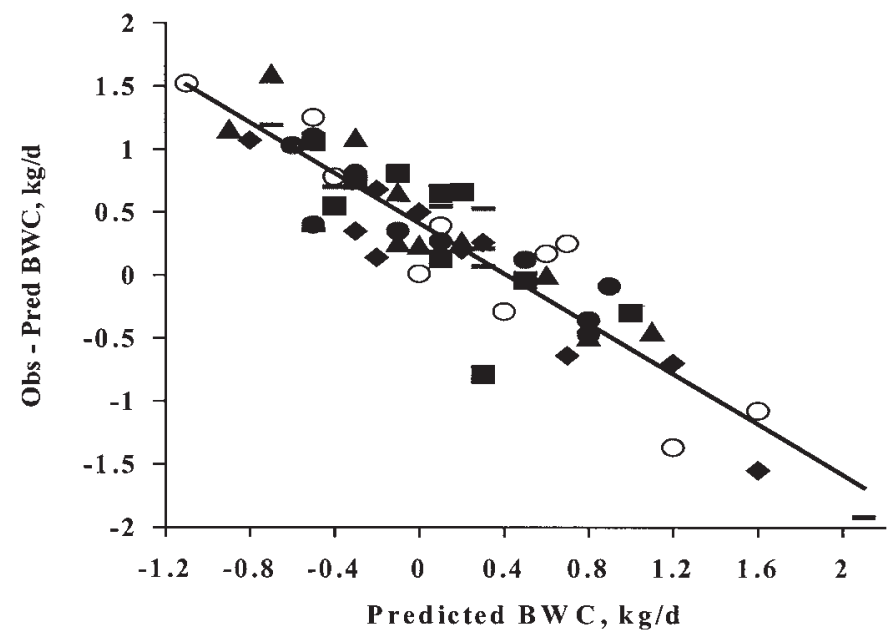

Figure 1. Residuals (observed-predicted) vs. predicted BW change (BWC) obtained from inputs into the NRC (2001) model. Data represent means from BW change actually measured over the 16 -wk period during which dairy cows were fed a $21 \%$ forage NDF control (-); low

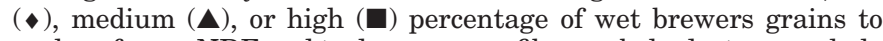
replace forage NDF and to decrease nonfiber carbohydrates; or whole linted $(\bigcirc)$ or Easiflo $(\bullet)$ cottonseeds fed in diets similar to the high wet brewers grains diet. The slopes of observed-predicted residual BW change regressed against predicted BW change were similar among treatments, with a common linear regression (solid line) of $0.41(\mathrm{SE}=0.04)-1.00(\mathrm{SE}=0.06) \times$ predicted $\mathrm{BW}$ change.

in lactation performance to decreasing $\mathrm{NE}_{\mathrm{L}}$ concentration, however, a more detailed evaluation of energy usage was performed using the NRC (2001) model. No changes were detected in $\mathrm{NE}_{\mathrm{L}}$ intake or output, and the output:intake ratios for $\mathrm{NE}_{\mathrm{L}}$ ranged from 0.974 to 0.996 (average 0.99 ), which document the accuracy of the NRC (2001) model for mean responses over this range in diet composition. Apparently, the decrease in $\mathrm{NE}_{\mathrm{L}}$ concentration with increasing WBG was not large enough to affect $\mathrm{NE}_{\mathrm{L}}$ intake or lactation performance significantly, further emphasizing the dominant role of DMI to regulate the amount of milk produced.

Because the NRC (2001) model was used to assess energy usage for which no independent observations could be made, BW change was chosen to evaluate the model predictions compared with actual measurements. Neither treatment nor treatment $\times$ predicted BW change effects were detected $(P>0.10)$ when residuals of BW change were regressed against predicted BW change, so the final model had only predicted BW change as an independent variable (Figure 1). Energy balance ranged from 0.3 to $1.3 \mathrm{Mcal} / \mathrm{d}$ (Table 3). At a BCS of $2.5,1 \mathrm{~kg} / \mathrm{d}$ of BW gain should require about $4.9 \mathrm{Mcal} / \mathrm{d}$ of $\mathrm{NE}_{\mathrm{L}}$ (NRC, 2001). Thus, cows would be predicted to gain about 0.06 to $0.27 \mathrm{~kg} / \mathrm{d}$ (energy balance divided by $4.9 \mathrm{Mcal} / \mathrm{d}$ ), which underestimated observed BW change $(0.41 \mathrm{~kg} / \mathrm{d}$ mean across treatments) by an average of about $0.25 \mathrm{~kg} / \mathrm{d}$. At a predicted BW change of $0 \mathrm{~kg} / \mathrm{d}$, the y-intercept of observed-predicted BW change $(0.41 \mathrm{~kg} / \mathrm{d}$; Figure 1$)$ was slightly higher than $0.25 \mathrm{~kg} / \mathrm{d}$ because $1 \%$ of the input of $\mathrm{NE}_{\mathrm{L}}$ was not accounted for as output. The regression coefficient of -1.00 $(\mathrm{SE}=0.06$; Figure 1) documented a strong linear bias when individual cow data were used. Our data were within the range of evaluation data (Figure 16-2) in the NRC (2001), but the evaluation data were treatment means from published literature. Because the linear bias was not impacted by treatment (random representation of treatments over the range of the regression), any errors in estimation of $\mathrm{NE}_{\mathrm{L}}$ intake or $\mathrm{NE}_{\mathrm{L}}$ output terms probably were amplified in the $\mathrm{NE}_{\mathrm{L}}$ balance and predicted BW change for individual cows, but the errors cancelled when grouped by treatment.

\section{CONCLUSIONS}

In conclusion, if forage NDF is replaced with byproduct NDF concomitantly with decreasing NFC, lactation performance was similar. These data support the NRC (2001) minimum forage NDF recommendations and revised energy system for evaluation of treatment means.

\section{REFERENCES}

Allen, D. M., and R. J. Grant. 2000. Interactions between forage and wet corn gluten feed as sources of fiber in diets for lactating dairy cows. J. Dairy Sci. 83:322-331.

Allen, M. S. 2000. Effects of diet on short-term regulation of feed intake by lactating dairy cattle. J. Dairy Sci. 83:1598-1624.

Association of Official Analytical Chemists. 1990. Official Methods of Analysis. 15th. AOAC, Arlington, VA.

Bernard, J. K. 1999. Performance of lactating dairy cows fed whole cottonseed coated with gelatinized cornstarch. J. Dairy Sci. 82:1305-1309.

Bernard, J. K., M. C. Calhoun, and S. A. Martin. 1999. Effect of coating whole cottonseed on performance of lactating dairy cows. J. Dairy Sci. 82:1296-1304.

Bernard, J. K., S. A. Martin, and T. C. Wedegaertner. 2001. In vitro mixed ruminal microorganism fermentation of whole cottonseed coated with gelatinized corn starch and urea. J. Dairy Sci. 84:154-158.

Broddugari, K., R. J. Grant, R. Stock, and M. Lewis. 2001. Maximal replacement of forage and concentrate with a new wet corn milling product for lactating dairy cows. J. Dairy Sci. 84:873-884.

Clark, P. W., and L. E. Armentano. 1993. Effectiveness of neutral detergent fiber in whole cottonseed and dried distillers grains compared with alfalfa haylage. J. Dairy Sci. 76:2644-2650.

Coppock, C. E., J. R. Moya, J. W. West, D. H. Nave, J. M. Labore, and C. E. Gates. 1985. Effect of lint on whole cottonseed passage and digestibility and diet choice on intake of whole cottonseed by Holstein cows. J. Dairy Sci. 68:1198-1206.

Davis, C. L., D. A. Grenawalt, and G. C. McCoy. 1983. Feeding value of pressed brewers' grains for lactating dairy cows. J. Dairy Sci. 66:73-79.

Eastridge, M. L., and J. E. Winkler. 1998. Ohio Dairy Ration Program User's Guide. The Ohio State Univ., Columbus.

Firkins, J. L. 1997. Effects of feeding nonforage fiber sources on site of fiber digestion. J. Dairy Sci. 80:1426-1437.

Goering, H. K., and P. J. Van Soest. 1970. Forage Fiber Analyses (Apparatus, Reagents, Procedures, and Some Applications). 
Pages 1-20 in Anonymous (Ed.) Agric. Handbook No. 379. ARSUSDA, Washington, DC.

Grant, R. J. 1997. Interactions among forages and nonforage fiber sources. J. Dairy Sci. 80:1438-1446.

Harvatine, D. I., J. L. Firkins, and M. L. Eastridge. 2002a. Whole linted cottonseed as a forage substitute fed with ground or steamflaked corn: Digestibility and performance. J. Dairy Sci. 85:1988-1999.

Harvatine, D. I., J. E. Winkler, M. Devant-Guille, J. L. Firkins, N. R. St-Pierre, and M. L. Eastridge. 2002b. Whole linted cottonseed as a forage substitute: Fiber effectiveness and digestion kinetics. J. Dairy Sci. 85:1976-1987.

Mertens, D. R. 1997. Creating a system for meeting the fiber requirements of dairy cows. J. Dairy Sci. 80:1463-1481.

Mooney, C. S., and M. S. Allen. 1997. Physical effectiveness of the neutral detergent fiber of whole linted cottonseed relative to that of alfalfa silage at two lengths of cut. J. Dairy Sci. 80:2052-2061.

National Research Council. 1989. Nutrient Requirements of Dairy Cattle. 6th rev. ed. Natl. Acad. Sci., Washington, DC.

National Research Council. 2001. Nutrient Requirements of Dairy Cattle. 7th rev. ed. Natl. Acad. Sci., Washington, DC.
SAS. 1999. What's New in SAS Software for Version 7 and the Version 8 Developer's Release. Release 7. SAS Inst., Cary, NC.

Slater, A. L., M. L. Eastridge, J. L. Firkins, and L. J. Bidinger. 2000. Effects of starch source and level of forage neutral detergent fiber on performance by dairy cows. J. Dairy Sci. 83:313-321.

Sukhija, P. S., and D. L. Palmquist. 1988. Rapid method for determination of total fatty acid content and composition of feedstuffs and feces. J. Agric. Food Chem. 36:1202-1206.

Tyrrell, H. F., and J. T. Reid. 1965. Prediction of the energy value of cow's milk. J. Dairy Sci. 48:1215-1223.

Van Soest, P. J., J. B. Robertson, and B. A. Lewis. 1991. Methods for dietary fiber, neutral detergent fiber, and nonstarch polysaccharides in relation to animal nutrition. J. Dairy Sci. 74:35833597.

Varga, G. A., H. M. Dann, and V. A. Ishler. 1998. The use of fiber concentrations for ration formulation. J. Dairy Sci. 81:3063-3074.

Weiss, W. P. 1993. Predicting energy values of feeds. J. Dairy Sci. 76:1802-1811.

Younker, R. S., S. D. Winland, J. L. Firkins, and B. L. Hull. 1998. Effects of replacing forage fiber or nonfiber carbohydrates with dried brewers grains. J. Dairy Sci. 81:2645-2656. 